\title{
NUMERICAL MODELS USED FOR THE CALCULATION OF THE CABLE-STAYED BRIDGE AT KM 0+540 OVER DANUBE-BLACK SEA CANAL
}

\author{
Mutu Costin Stelian, engineer, S.C. I.P.T.A.N.A. S.A., e-mail: costinmutu@yahoo.com \\ Răcănel Ionuţ Radu, assoc.prof., Strength of Materials, Bridges and Tunnels Department, \\ Technical University of Civil Engineering of Bucharest, e-mail: ionut_racanel@yahoo.com
}

\section{Rezumat}

Podurile cu hobane sunt structuri complexe pentru a căror proiectare, metodele tradiţionale de calcul sunt greu, chiar aproape imposibil de utilizat pentru o analiză globală. Analiza separată a elementelor componente ale structurii se poate face prin metode simplificate însă în acest caz conlucrarea spaţială dintre elemente nu este luată în considerare şi pot interveni erori în aprecierea răspunsului structurii. În cazul acestor structuri, tehnologia de execuţie şi prezenţa hobanelor, care sunt elemente cu o comportare neliniară, implică considerarea tuturor etapelor de execuţie, inclusiv a efectelor de ordinul II, pentru a putea transmite starea de eforturi şi deformaţii până în fază finală.

În prezent, datorită evoluţiei şi perfecţionării metodelor de calcul şi tehnicii în domeniul calculatoarelor electronice, podurile cu hobane pot fi analizate cu suficientă acurateţe astfel încât răspunsul obţinut să se apropie mult de comportarea structurii, atât pe durata execuţiei, cât şi în exploatare.

Scopul acestei lucrări este de a prezenta rezultatele obţinute utilizând unul din modelele de calcul cu elemente finite şi calculul neliniar pe etape de execuţie al podului de la $\mathrm{km} 0+540$ peste Canalul Dunăre-Marea Neagră în apropiere de Agigea. În lucrare vor fi prezentate rezultate legate de evoluţia stării de eforturi şi deformaţii în elementele principale ale podului - piloni, hobane, tablier - rezultate din analizele efectuate.

Cuvinte cheie: pod, hobană, pilon, analiză neliniară, efecte de ordinul II

\section{Abstract}

Cable-stayed bridges are complex structures and for their design, the traditional calculation methods are hard, even impossible to use for a global analysis. Separate analyses for the each component of the bridge in a simplified manner can be conducted, but in this case the concurrence of the elements into the structure is not taken into account, leading to errors in estimating the structural response. For these structures, the construction method and the presence of the stays, which are elements having a nonlinear behaviour, implies to consider a 
nonlinear staged analysis including the second order effects in order to transmit form one stage to the other the stress-strain state.

In the present time, thanks to the evolution and development of the calculation methods and computer analysis, cable-stayed bridges can be accurate analysed so that the obtained response is close to the behaviour of the structure during erection and later, in service.

The aim of this paper is to present the results obtained using one of the finite element models and nonlinear staged analysis of the bridge at km 0+540 over Danube-Black Sea Canal near Agigea. Inside the paper, results related to the evolution of stress-strain state in principal structural elements of the bridge - pylons, stays and deck - during the execution and in final stage, in service are to be presented.

Keywords: bridge, stay, pylon, nonlinear analysis, second order effects

\section{INTRODUCTION}

Cable-stayed bridges are multiple statically indeterminate structures and this is the reason why for establishing the stress-strain state in the structural elements complex calculation procedures must be used. The difficulty of calculation appears not only because of the evaluation of a large number of parameters imposed by the presence of the stays, but also because of the geometric nonlinearities that should be considered. For these structures, the axial forces in the stays varies according to their deformed shape and for having correct results, the analysis must be carried out in many steps, by controlling and correcting the forces and displacements.

For a correct design in the case of a cable-stayed bridge it is necessary to take into account the stages during the construction process. Generally, for these kind of structures the cantilevering is used to take benefits from the presence of the stays, but are situations when for some parts of the structure the bearing on temporary towers is necessary. Thus, for limiting the vertical displacements of new added in each stage superstructure segments, the axial forces in the stays must be carefully computed and correlated with both, with the already introduced stays and the displacements at the top of the towers. Usually, during the construction of a cable-stayed bridge, in each stage, when a new segment is added, corrections are to be done in order to obtain the desired pre-deformed shape of the structure. These aspects must be considered into the adopted calculation method.

The occurrence and development of the computational techniques together with the development of modern methods for structures analysis allow today the construction of numerical models containing a large number of variables, both in 
terms of materials behaviour and the taking into account of the deformed shape of the structure during analysis.

This paper aims to present the results of the static and dynamic analyses on finite element models for the new cable-stayed bridge at Agigea, over the Danube-Black Sea Canal at km 0+540. In the design stage, several solutions for the bridge superstructure were studied, the final one consisting in considering a composite structure in the central span and hybrid in the lateral spans. The present study was performed on the initial solution, the whole superstructure being composite.

\section{DESCRIPTION OF THE BRIDGE}

The cable-stayed bridge is placed at $\mathrm{km} 0+540$ of Danube-Black Sea Canal, has an approximate length of $360 \mathrm{~m}$ covered with 3 spans: $80+200+80 \mathrm{~m}$. In plain view, a part of the bridge, approximately $247 \mathrm{~m}$ is in alignment, the rest of $113 \mathrm{~m}$ being placed on a curve having a radius of $380 \mathrm{~m}$. In elevation, the bridge is on a convex connection with a vertical radius of $5000 \mathrm{~m}$, connecting the two longitudinal gradients: through the left river edge, on the zone placed in alignment, having a slope of $1.1 \%$ and through the right edge including the zone placed on the curve, having a slope of $3.2 \%$.

From the point of view of stays arrangement there are two planes of stays, one each side with respect to the longitudinal axis of the bridge, in fan system. Eight pairs of stays are placed each side of the pylons. The distance between the theoretical anchoring points of stays at superstructure level is $8.50 \mathrm{~m}$ in lateral spans and $10 \mathrm{~m}$ in the central span (Fig.1,2).

The bridge superstructure sustains a carriageway having the width of $14.80 \mathrm{~m}$, with 4 lanes, and two footways, two lanes and one footway each side of the bridge. The separation between carriageway and footways is made using high curbs.

The bridge substructure consists in two pier-abutments and two pylons (Fig.1,2). The height of the pier elevation on the left river edge is $12.70 \mathrm{~m}$, while of the pier on the right edge is $10.20 \mathrm{~m}$. The piers were built in reinforced concrete, with a lamellar elevation with variable width. The pier-abutments foundation is on drilled piles having diameters between 1.20 and $1.50 \mathrm{~m}$ and lengths of $24 \mathrm{~m}$ (on the left edge) and $20 \mathrm{~m}$ (on the right edge) respectively.

The pylons were designed as frames with two columns (Fig.2) and have a height of $61 \mathrm{~m}$ over the piles cap level. At the height of $16.50 \mathrm{~m}$ above the piles cap, the cross section of the pylon columns is rectangular, in reinforced concrete, with the dimensions of $2.50 \mathrm{~m}$ in transverse direction and variable between 6.00 and 


\section{ROMANIAN JOURNAL OF TRANSPORT INFRASTRUCTURE}

Mutu Costin Stelian, Răcănel Ionuț Radu

Numerical models used for the calculation of the cable-stayed bridge at km 0+540 over Danube-Black Sea Canal

$5.12 \mathrm{~m}$ in longitudinal direction. Starting with the level of $16.50 \mathrm{~m}$ up to the level of $30 \mathrm{~m}$ above the piles cap, the cross section of the two columns forming the pylon is a reinforced concrete box with a constant dimension of $2.50 \mathrm{~m}$ in transverse direction and variable between 5.12 and $3.40 \mathrm{~m}$ in longitudinal direction. The box walls have a thickness of $0.65 \mathrm{~m}$ in transverse direction and variable thickness between 0.80 and $1.60 \mathrm{~m}$ in longitudinal direction. Starting at $30 \mathrm{~m}$ above the piles cap level up the upper end of the pylons, the cross section is composite. The structural elements linking the pylon columns are built also in reinforced concrete, the lower beam where the bearings are placed being prestressed for resist to the high level tension forces produced in service by external actions.
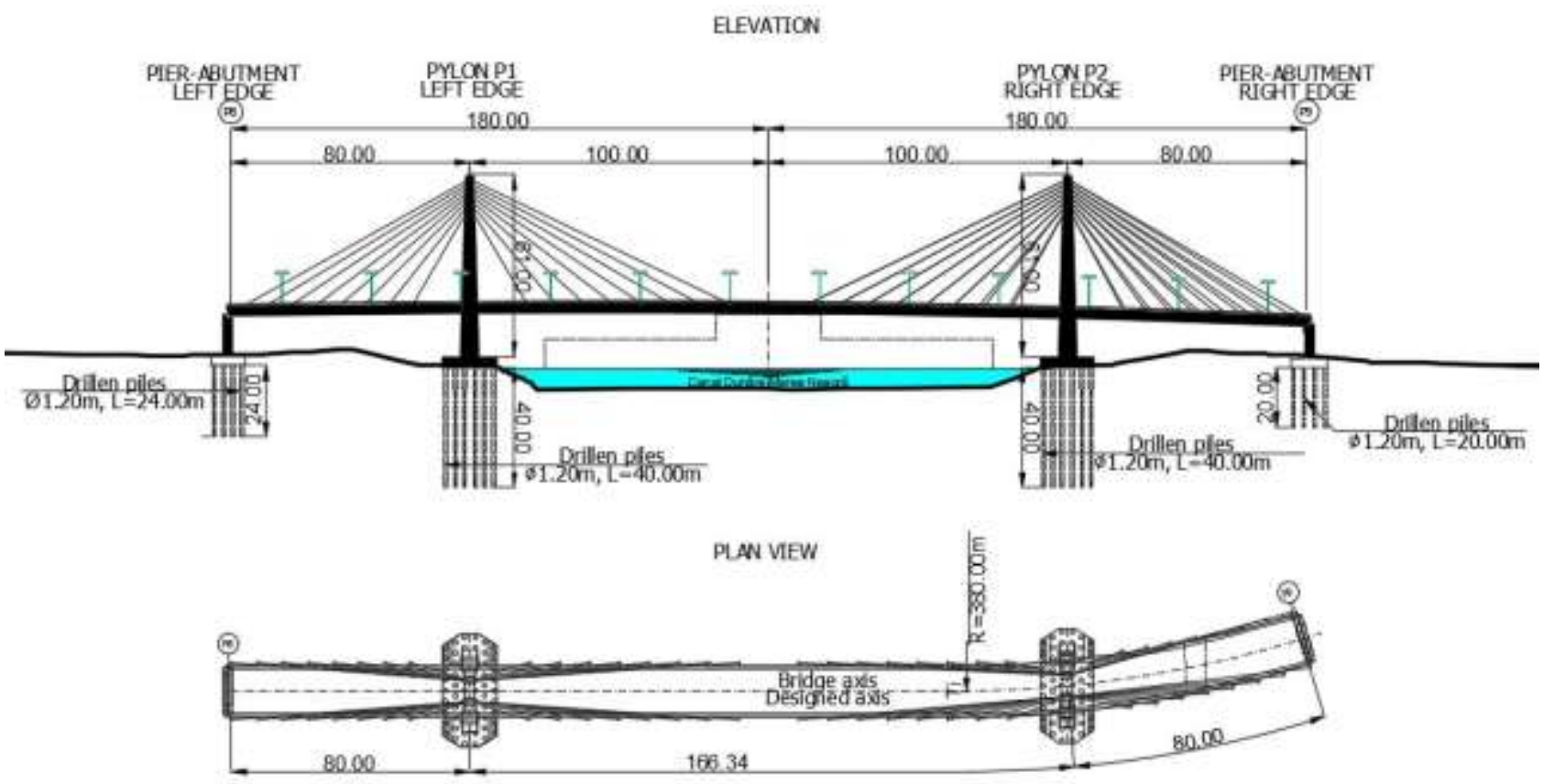

Figure 1. Elevation and plan view of the bridge 


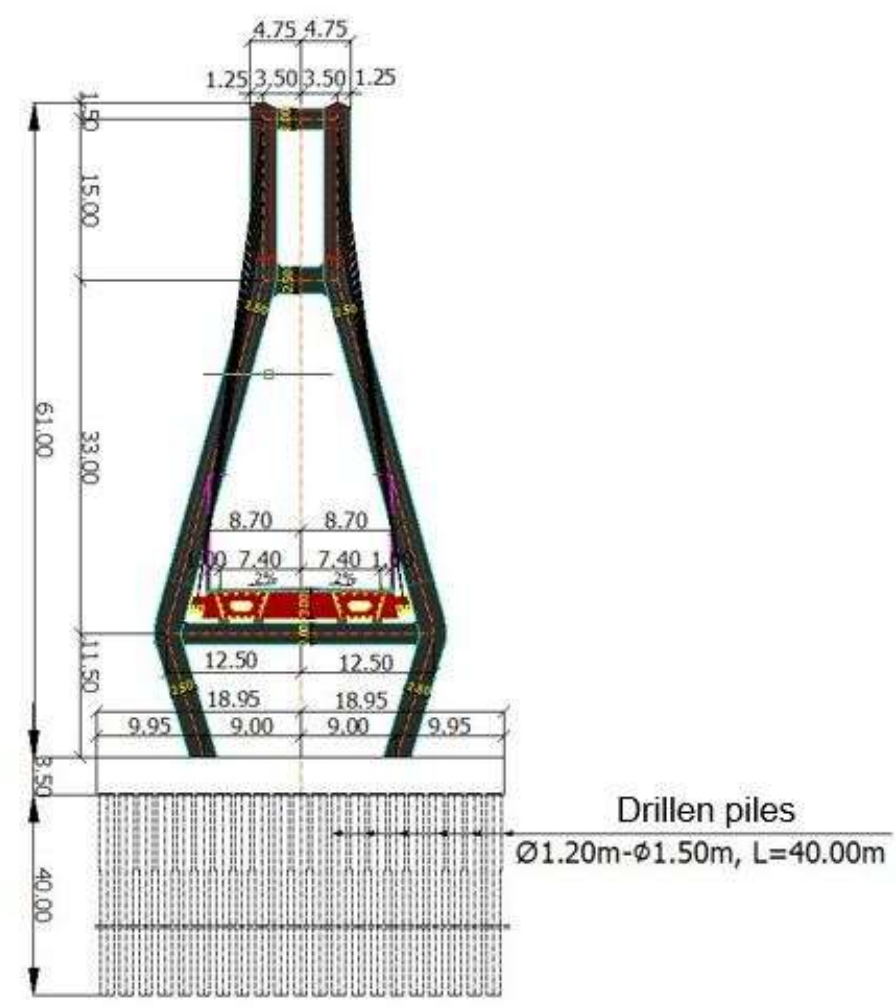

Figure 2. Cross section of the bridge

The bridge superstructure is composite and consists in two closed with inclined webs steel boxes forming the cross section. At the top part, the boxes are closed through a continuous steel plate having a thickness of $15 \mathrm{~mm}$ and stiffened between the inclined webs using longitudinal stiffeners with trapezoidal cross section. The steel plate was foreseen also on the entire width of the boxes, between the inclined webs for reducing the thickness of the concrete slab. At the bottom part, the steel boxes have a continuous plate $40 \mathrm{~mm}$ thick, reinforced also with closed cross section stiffeners. In transverse direction, the two boxes are connected through cross beams having box cross sections in the sections where the stays are anchored and through cross beams with open cross section ("I" form) placed midway between the stays anchoring points.

The concrete slab at the top part of the steel structure has a variable thickness starting from $16 \mathrm{~cm}$ under the footways and rising to $25 \mathrm{~cm}$ in the bridge longitudinal axis. The transverse slope of the concrete slab is $2 \%$ as for the carriageway. The connection between the concrete slab and the steel structure is made through Nelson studs welded on the continuous steel plate ate the top of the steel boxes.

The stays were built with steel cables $15.7 \mathrm{~mm}$ diameter, having a strength of $1860 \mathrm{~N} / \mathrm{mm}^{2}$ and a minimum strain of $3.5 \%$. For the anchorage of the stays at the 
top part, in the pylon, a steel structure embedded into the concrete was designed (passive anchorage) and at the bottom part, active fixing anchorages placed on cantilever at the exterior side of the steel boxes ere foreseen. In order to avoid the lifting of the deck from the final bearings in the case of central span loading, the bridge superstructure has at both ends anchorage ears where special vertical hangers will be added.

The bearing of the deck on the substructure elements (pier-abutments and pylons) has to be done by special bearings, fixed on the pier-abutments and pylon P1 and mobile on the pylon P2.

\section{NUMERICAL MODELS USED IN THE ANALYSES}

For establishing the response of the structure under external loads the finite element method was used. Two models based on the original dimensions and geometry of the bridge were built:

a) a first model with the deck modelled based on the grillage solution (Fig.3);

b) a second model using plane finite elements with a combined membrane-plate behaviour (Fig.4).
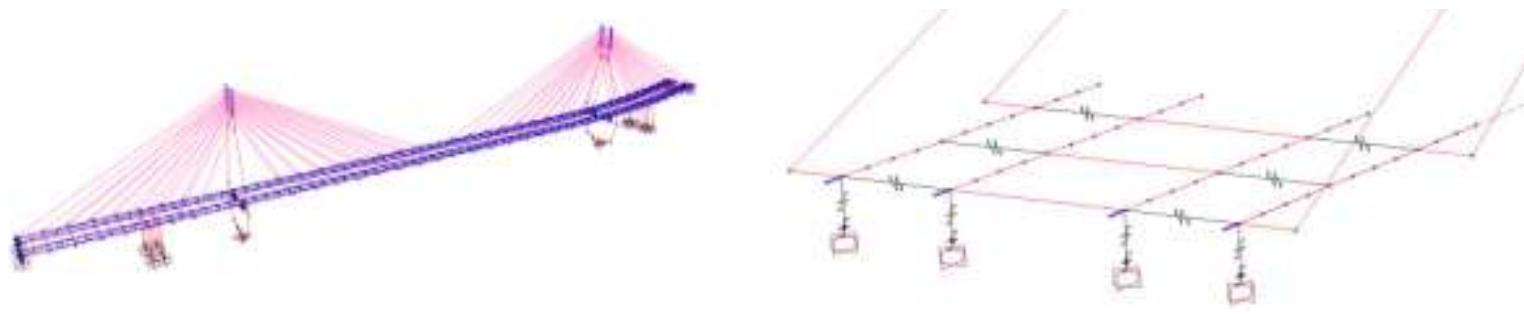

Figure 3. Finite element model based on the grillage solution
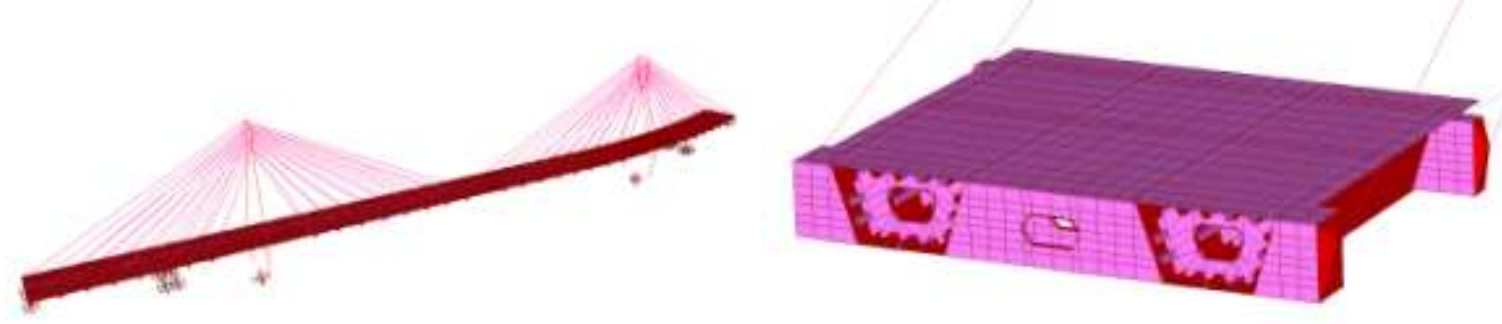

Figure 4. Finite element model with four nodes plane elements 
In the finite elements models the staged construction of the bridge was taken into account and the stress-strain state from a stage to the other was accounted for.

Following the performed analyses a good correlation between the results obtained by the mean of two models was achieved. As a consequence, the first simplified model based on the grillage solution was finally used for establishing the stress-strain level in the stays and pylons and the second model was used for determining the stress state in the steel girders and concrete slab.

In the first model (Fig.3) the bridge superstructure was modelled using two nodes straight beam elements $[1,2]$ with six degrees of freedom at each node (three translations and three rotations), forming the grillage. For accounting the high torsion stiffness of the steel boxes, high stiffness link elements were placed between the longitudinal components of the grillage modelling the walls of the steel boxes. At the anchorage points, at the bottom part of the elements modelling the stays, horizontal rigid link elements were also introduced.

In the second model (Fig.4) all structural elements in steel and concrete forming the bridge superstructure were modelled by mean of four nodes plane elements with a combined membrane-plate behaviour, based on the formulations in [2]. Inside the model, the connections between the concrete slab and steel boxes were introduced using rigid connection finite elements.

For modelling the pylons and the temporary towers existing in several stages in both models two nodes straight finite element were used. The pier-abutments were not introduced into the analyses because of the presence of the expansion joints between the superstructure of the main bridge and those of the access viaducts and thus the bridge response is not significantly influenced by their presence.

Concerning the foundations modelling, for the temporary towers used during the staged construction a fully fixed base was considered. The soil-structure interaction in the case of piles foundations was modelled by introducing springs with linear-elastic behaviour along the piles length. The variable with the depth spring stiffness was established based on the soil bedding on the site. For simplifying the finite element models, for the foundations of the two pylons the coupled stiffness of the straight beam finite elements and of the springs along them were replaced by equivalent joints linked to the ground by six springs: three for translations and three for rotations, using the theoretical aspects presented in $[3,4]$. The bearings on the two pier-abutments were restrained to the ground. 
The stays were modelled with cable finite elements including the nonlinear effects of changing the axial stiffness according to their deformed shape, but also second order effects because of large displacements.

The actions considered in the performed analyses were: self-weight of the structure, the weight of the green concrete, quasi-permanent loads (roadway layers, footways, crash barrier), concrete shrinkage, live loads, stays tensioning forces according to the construction stages, seismic action and wind dynamic action.

These actions were grouped according to the provisions in the standards using appropriate partial safety and grouping coefficients, both for persistent and transient design situations and for seismic situations. It was considered as possible the simultaneous existence of different type loads.

\section{PERFORMED ANALYSES. SUMMARY OF OBTAINED RESULTS}

For establishing the structural response under the considered actions, nonlinear static second order analyses, eigenvalue, seismic and eigenvalue buckling analyses were performed. Because of lack of space, in the frame of this paper, only the results of these analyses in terms of pylons, stays and main steel girders will be summarized.

\subsection{Nonlinear staged construction analysis}

In this analysis, 63 stages according to the construction technology were considered. These stages included the concreting of the pylons, the bearing on temporary towers of the superstructure segments brought on the site, the cantilevering of the superstructure segments, the sequentially tensioning of the stays etc. Following this analysis the distribution of stresses on the cross sections of the structural elements was established, together with the displacements of some interest points along the bridge, during the construction and in service. The checks of the structural elements cross sections for ultimate limit states but also for service limit state were performed using the Eurocodes. 

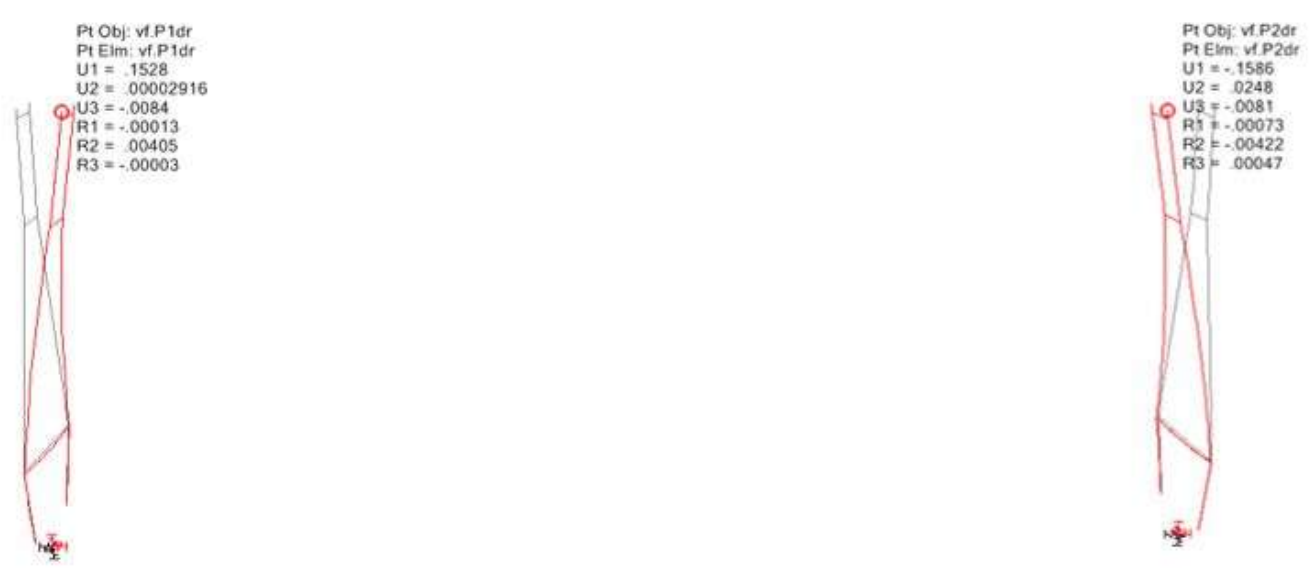

Figure 5. Maximum displacements at the top of the pylons

Figure 5 shows the deformed shape of two pylons including the maximum displacements during construction and in service and the graph in figure 6 contains the evolution of these displacements according to the stages considered into the analysis.

The following maximum values of the horizontal displacements at the top of the pylons (all in the last stage 63, with A30 vehicles and pedestrians over the central span) were obtained: $u_{V F . P 1-R I G H T}=0.153 \mathrm{~m}, u_{V F . P 1-L E F T}=0.153 \mathrm{~m}, u_{V F . P 2-}$ RIGHT $=-0.159 \mathrm{~m}, \mathrm{u}_{\mathrm{VF} . \mathrm{P} 2 \mathrm{-LEFT}}=0.162 \mathrm{~m}$.

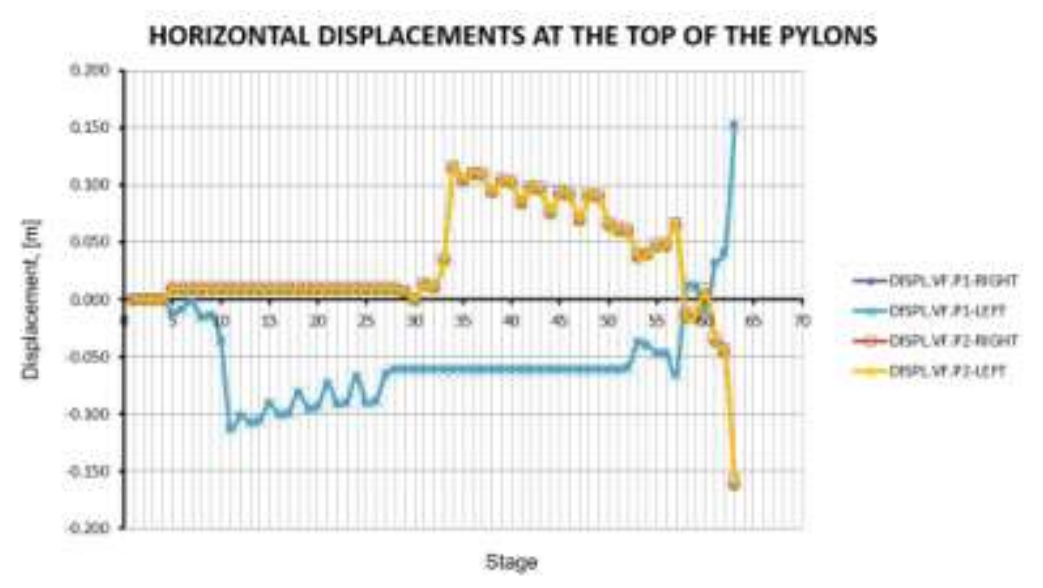

Figure 6. Evolution of the displacements at the top of the pylons during construction and in service

The axial forces in the stays could be established for each execution stage, the results for most unfavourable loading situations being used for resistance and fatigue checks. In figure 7 the coding of the stays on the bridge right side, at te pylon P1, is shown. 


\section{ROMANIAN JOURNAL OF TRANSPORT INFRASTRUCTURE}

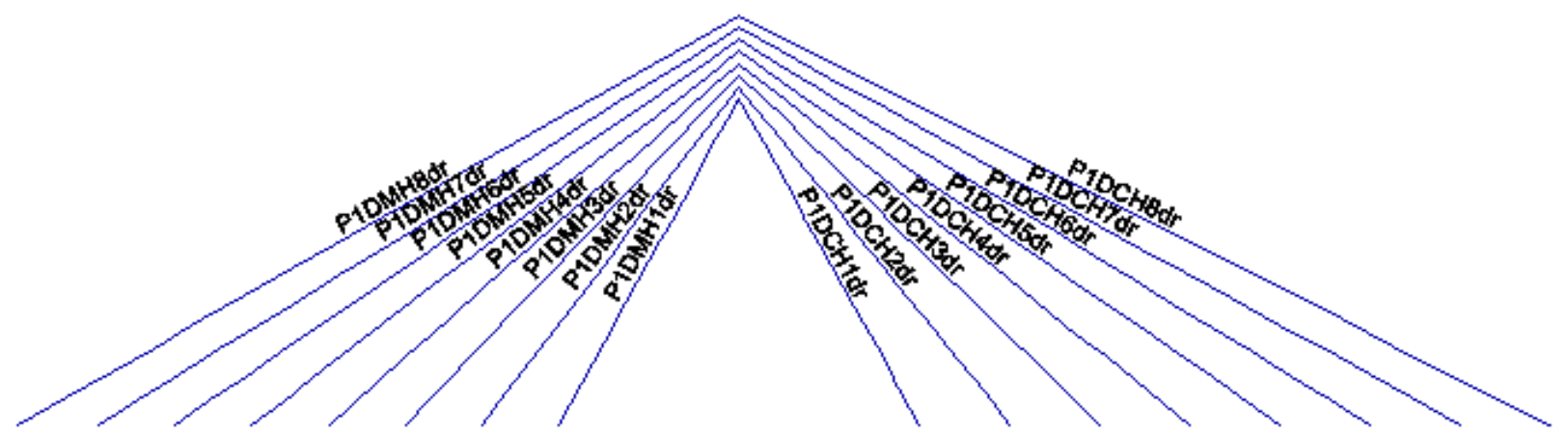

Figure 7. The coding of the stays on the bridge right side at the pylon P1

The figures 8-13 show the evolution of the axial forces in the stays according to each execution stage considered in the performed analyses.

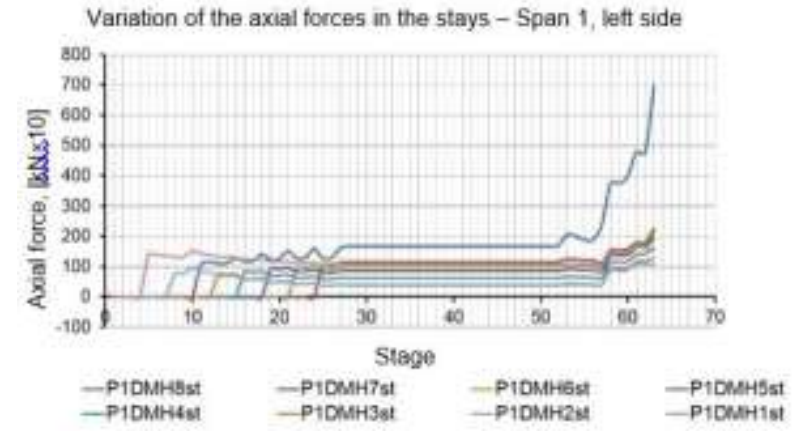

Figure 8. Evolution of axial forces in stays, span 1 , left side

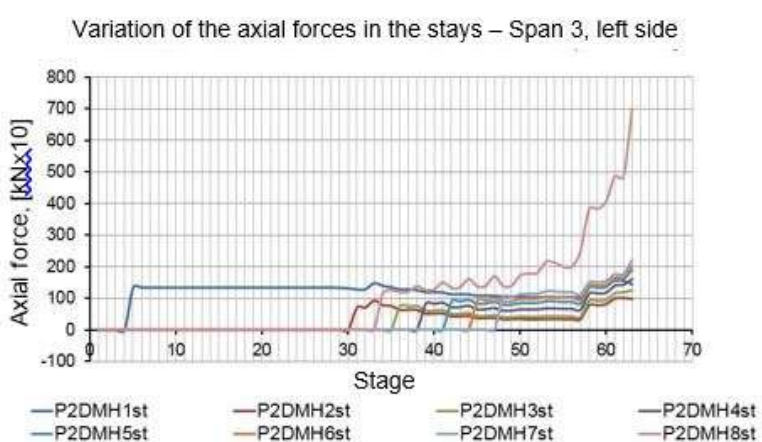

Figure 10. Evolution of axial forces in stays, span 3, left side

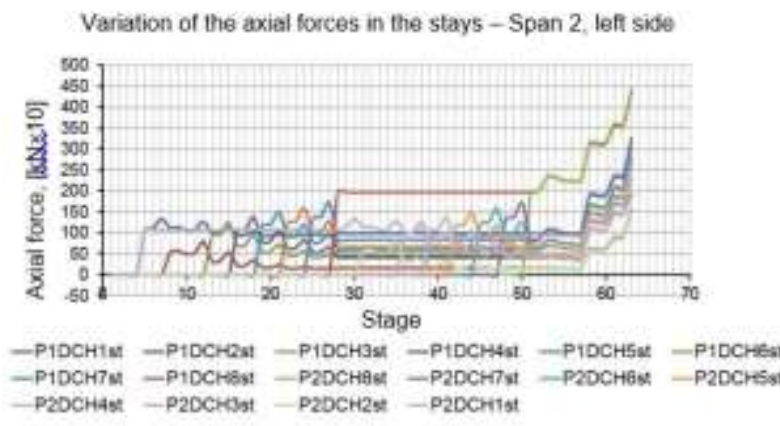

Figure 9. Evolution of the axial forces in stays, span 2, left side

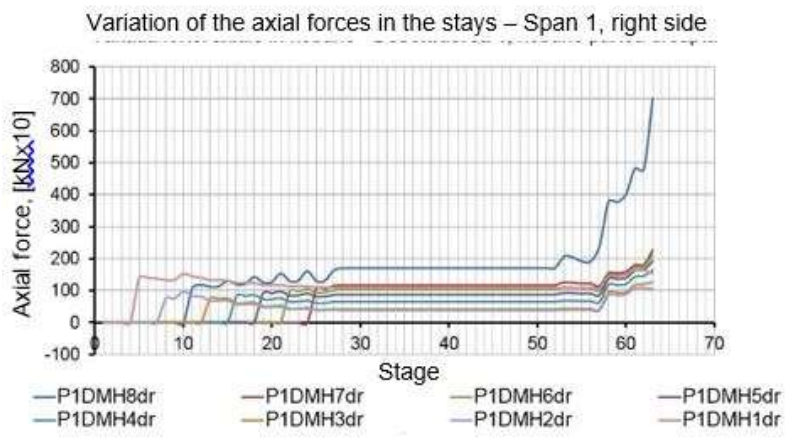

Figure 11. Evolution of axial forces in stays, span 1, right side 


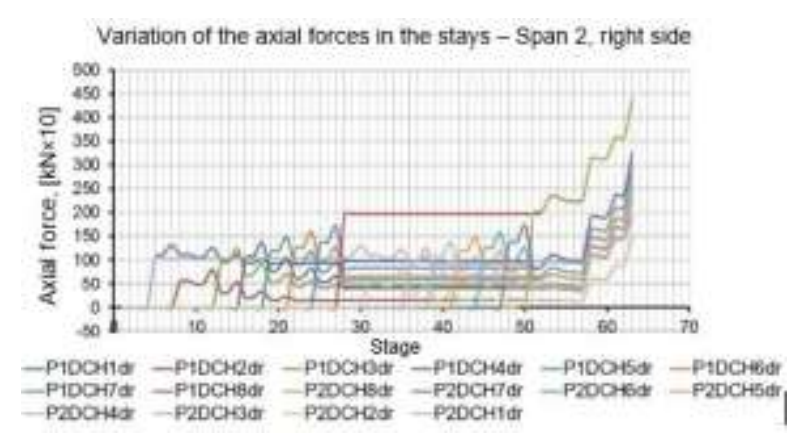

Figure 12. Evolution of axial forces in stays, span 2, right side

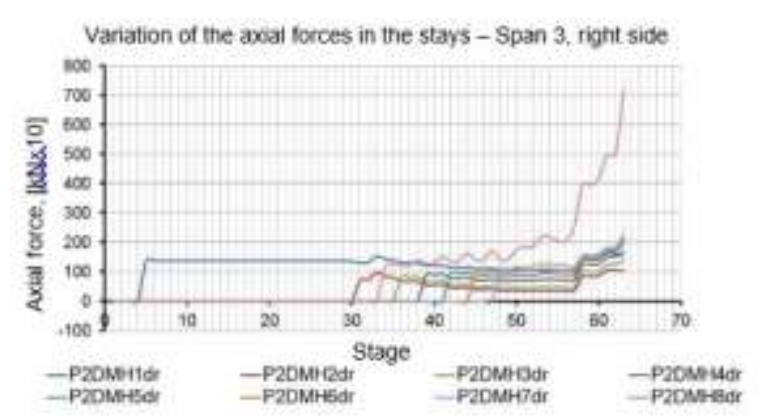

Figure 13. Evolution of axial forces in stays, span 3 , right side

\subsection{Eigenvalue dynamic analysis}

This analysis was conducted for establishing the dynamic characteristics of the structure in order to be used in a seismic response spectrum analysis, but also for establishing the dynamic response of the bridge under the wind action and the sensitivity for occurrence of phenomena as: fluttering, vortex shedding, galloping and divergence, together with the vibrations induced by wind and rain acting together.

In order to analyse the structure sensitivity to the wind action two calculation models were considered: during construction, when the structure is not yet finalized and the superstructure cantilever has maximum value and in the final stage, when the bridge is finished.

From the eigenmodes obtained following the linear dynamic analysis were chosen those corresponding to vertical bending, torsion and coupling between vertical bending and torsion.

Analyzing the values in the tables it can be seen that, for the stage during construction and with the maximum value for the superstructure cantilever, the eigenform corresponding to the vertical bending is the second $\left(f_{2}=0.824 \mathrm{~Hz}\right)$ and for the torsion the seven-th $\left(\mathrm{f}_{7}=2.596 \mathrm{~Hz}\right)$. For the second numerical model the same dominant vertical bending and torsion phenomena occur in eigenmodes one $\left(f_{1}=0.801 \mathrm{~Hz}\right)$ and ten respectively $\left(f_{10}=2.444 \mathrm{~Hz}\right)$. The deformed shape corresponding to these eigenvalues are presented in figures 14-17. 


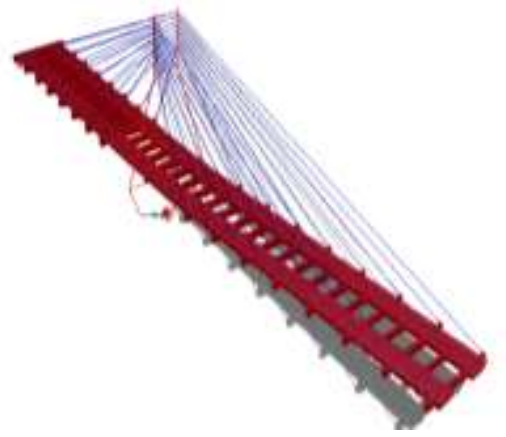

Figure 14. Mode $1, \mathrm{f}_{1}=0.736 \mathrm{~Hz}$ Bending, model cantilever

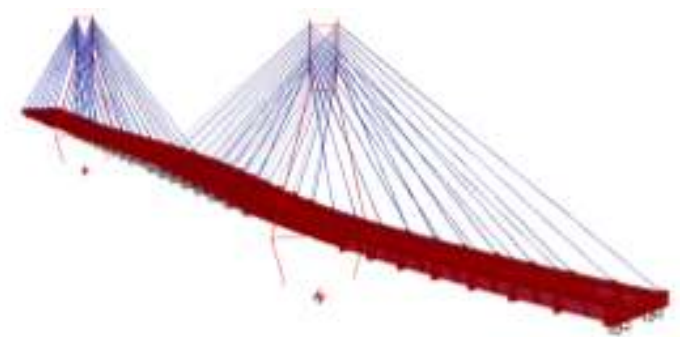

Figure 16. Mode $1, \mathrm{f}_{1}=0.801 \mathrm{~Hz}$ Bending, full model

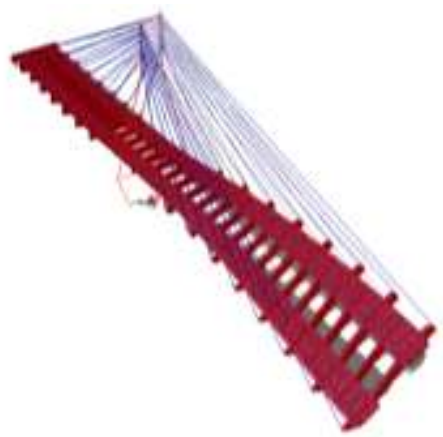

Figure 15. Mode 7, $\mathrm{f}_{7}=2.596 \mathrm{~Hz}$ Torsion, model cantilever

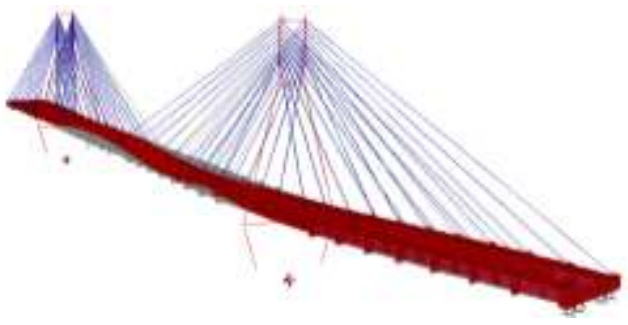

Figure 17. Mode $7, \mathrm{f}_{10}=2.444 \mathrm{~Hz}$ Torsion, full model

In table 1 are presented the critical speeds producing the aero elastic instability.

Table 1. Critical wind speed

\begin{tabular}{|l|r|}
\hline \multicolumn{1}{|c|}{ Instability phenomena } & Critical speed [m/s] \\
\hline Flutter & 198.35 \\
\hline Vortex shedding & 107.60 \\
\hline Galloping & 18.04 \\
\hline Divergence & 55.40 \\
\hline
\end{tabular}

\section{CONCLUSIONS}

The use of complex calculation models allow the establishing of the response of the cable-stayed bridge over the Danube-Black Sea Canal at km $0+540$ both, statically and dynamically. Following the performed analyses the following conclusions can be pointed out:

- maximum displacements at the top of the pylons of $162 \mathrm{~mm}$ considering the load combinations with live loads in the central span are bellow the limit value of $\delta_{\max }=\mathrm{H} / 300=6000 / 300=20 \mathrm{~cm}(\mathrm{H}$ being the pylon height above the piles cap); 
- there are stays/cables (P1DCH2dr, P2DCH2dr, P1DCH2st, P2DCH2st) that are not fulfilling the fatigue checking criteria according to SR EN 1993-2 considering very heavy traffic. For these stays the recommendation for increasing the cables dimensions (diameter) was made;

- the obtained results show the fulfilling the checking criteria at ULS (ultimate limit state) and FLS (fatigue limit state) for most stressed sections of steel boxes forming the bridge superstructure;

- following the performed checks it can be concluded that the cross beams and longitudinal stiffeners are fulfilling the criteria for ULS and FLS;

- the maximum sag of the superstructure considering the central span loaded with five rows of vehicle corresponding to A30 convoy has the value of $\mathrm{f}_{\max }=0.356 \mathrm{~m}$, bellow the allowable value of $\mathrm{f}_{\mathrm{a}}=\mathrm{L}_{2} / 300=0.667 \mathrm{~m}$;

- regarding the risks for the occurrence of local (buckling) and general instability it can be concluded that such phenomena are not possible for the components of the steel superstructure;

- there is no risk for the occurrence of aero elastic instability, the structure being well conformed, with sufficient bending and torsion stiffness.

\section{References}

[1]. K.J.BATHE, E.L.WILSON: "Numerical methods in finite element analysis", New York: Prentice Hall, Englewwod Cliffs, 1976.

[2]. E.L.WILSON: "Three-dimensional static and dynamic analysis of structures", Berkeley: Computers and Structures Inc., 2002.

[3]. J.S.PRZEMIENECKI: “Theory of matrix structural analysis”, New York: Mc GrawHill, 1968.

[4]. G.ONU: "Calculation of pile caps", Studies and research of aplied mechanics, Extras, nr.4, Tomul 33, Editura Academiei, 1974. 